\title{
ドリン 剤中毒に関する研 究
}

\author{
第 3 編 \\ ドリン 剂 中毒の統計 的 観 察
}

岡山大学医学部平木内科教室 (主任 : 平木 橴教授)

新谷善 治

(昭和 38 年 12 月 11 日受稿)

I 粕 言

II 調查方法

III 調奋成簀

\section{I. 楮 言}

近年農薬が大量に使用されるようになり，連年の 大脰作の一因となつている事は周知の通りである。 しかしながら同時に農薬中毒が頻々とみられるよう になつており，その予防，治療対策は極めて重要な 事柄となつている，そのうち有機燐剂については， その作用機序がコリンエステラーゼの活性を抑制す るととにあるという事が明らかとなり，根本的治療 剂である PAM 療法が殆んど完成をみたと云われて いる，他方リンン剂については尚作用機序は不明で。 治療も対症療法の域を出ず，重症中毒の場合は殆ん ど救助し難い現状である，著者は我が国に於けるド リン剂中毒の現状を明らかにする為, 各都道府県へ 行われた報告 129 例を集計したのでととに報告す る.

\section{II 铜查方法}

農薬中毒の発生状況は毎年厚生省より発表されて いる. その中でエンドリン中毒の発生している各都 道府県へ調查表を配付し，回答を求めた。中毒発生 後訩療した医師から所轄保健所へ届けられた状况か 各都道府県へ集計された結果である. 我が国でのド リン刘中毒杜第 1 表にみられるように昭和33年以来 36年迄にエンドリン中毒が163例，アルドリン中毒 が1例報告されている．デイルドリン中毒杜全く発 生していない.

\section{III 铜查成粮}

1. 原因
次

$$
\text { IV 総括並に考按 }
$$

$\mathrm{V}$ 結 諭

第 1 表 ドリン剂生産量及び中毒患者数

\begin{tabular}{l|r|r|r|r|r|r|r}
\hline \hline 年度別!昭和 & 31 & 32 & 33 & 34 & 35 & 36 & 計 \\
\hline 区分 & 30 年 & 31 & & & & & \\
\hline
\end{tabular}

（厚生省の統計による）

エンドリン中毒163例中140例（8696）は自殺を目 的とする内服死亡例である. 撒布又は品用に上る中 毒は11例が報告されているが，うち7名の死亡例は 何れあ誤用例である. 誤用例の中には井戸に投入さ れた事を知らずに井戸水を飲用し，家族 7 名が頭㴼， はきけを来たしたものや,ウィスキ一の瓶に入れて あつたものを誤飲したものが2例, 誤つて手の創口 にエンドリン乳剂を多量に塾布し死亡したものとか， 保管が悪い為幼児が誤用した等の報告がるられる.

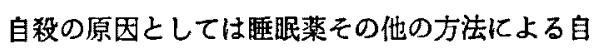
殺之同㥞であるが神経衰弱によるものが最も多く， 家庭不和, 結㛰問題, 病気, 㴨世によるもの等が報 告されている.

他殺として報告されているすのは，母親加自殺の 際，子供を道連れにしたものが大部分である.

2. 服用量及び症状発現迄の時間

内服死亡例のうち服用量の記載のある6のは19.5 名エンドリン乳刘 3cc から300ec 迄で, 10cc の1 例と 80ccの1峢以外㤬全例死亡しており，服用是 最低の $3 \mathrm{cc}$ 服用例は14才の女子で約 2 時間後死亡 し，5cc 服用の18才の女子及び $10 \mathrm{cc}$ 服用の 3 例の 
うち，15才の男子及び56才の女子の 2 例む，何れも 死亡している.

内服後症状発現迄の時閒は記截あるすのが少いか 大体20分から 1 時間で非常に速やかである. 死亡迄 の時間は25分から数時間で死亡しているが， 1 時間 から 4 時間の間に大部分が死亡している.

3. 発生季節 (第 2 表)

第 2 表 月及び性別エンドリン中毒患者数

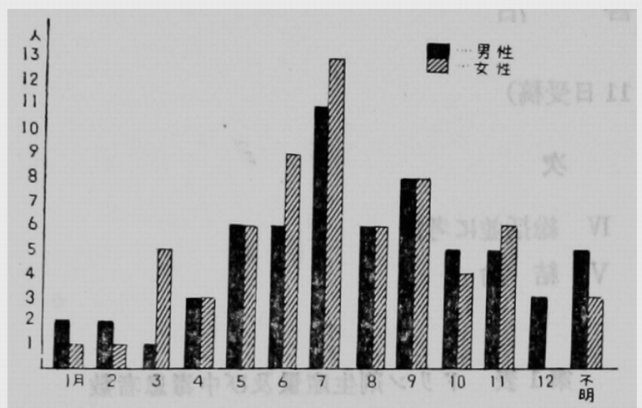

ドリン剂の使用量が增加する 5 月から11月に多い が 7 月に最も多く発生している.

4. 性及び年令別エンドリン中毒患者数(第 3 表) IF性別では女子に稍々多く，年令別では20 30才に 最も多く，41〜45才の男には発生していない.

5. 臨床症状

(A) 軽症中毒例

第1例, 29才，女

33年 7 月 6 日エンドリン乳剂を素足, 素手にて調 合，撒布した所帰宅後頭痛，悪心，嘔吐，顔面荅白， 発熱があつた，対症療法を行い 4 日後に恢復した。

第 2 例26才，女

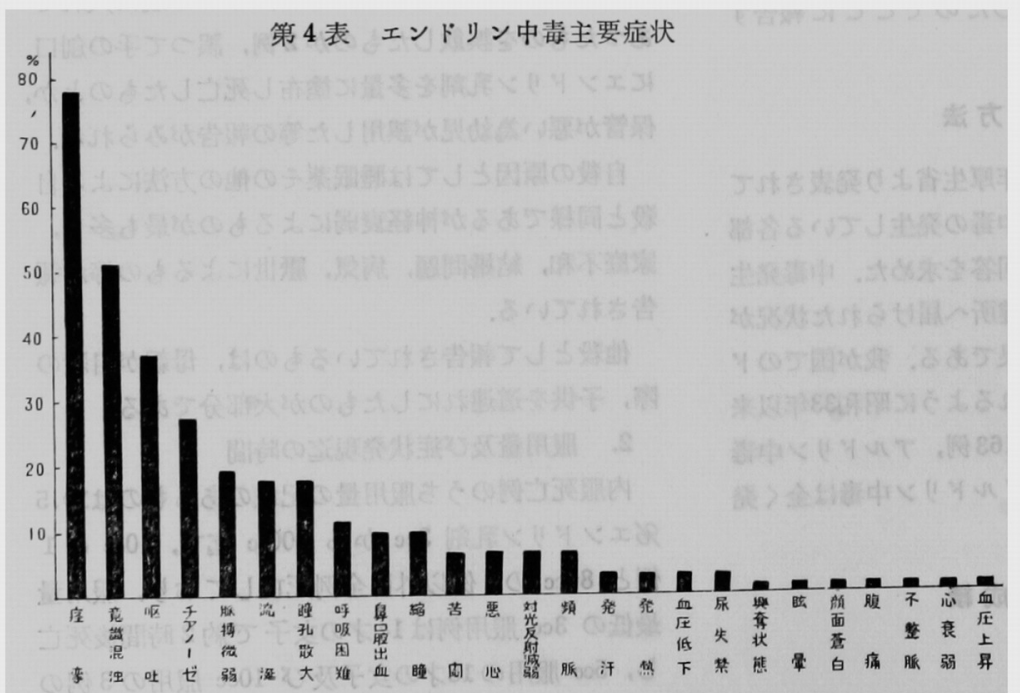

第 3 表 年令及び性別エンドリン中毒患者数

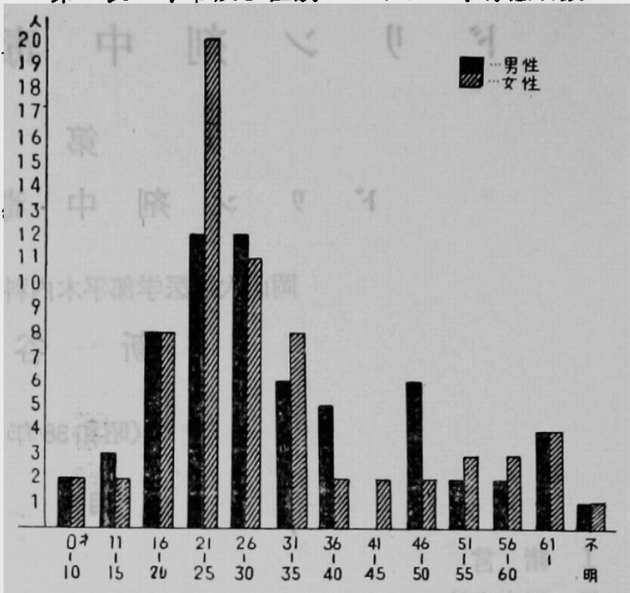

35年 5 月23日 19.5\%エンドリン乳剂を約 500 倍に 稀釈しトマトに撒布した．翌24日昼頃より食思不振， はきけがあつた，25日は朝から頭重，倊念感，関節 痛, 筋肉痛があり，終日頭痛，不眠があつた，対症 療法にて軽快した。

以上 2 例とあ他佰因と考えられるものなくエン ドリン中毒と報告された。

(B) 重症中毒例

第 4 表の如き症状か報告されており，全身の激し い座攀発作, 意譜混濁, 嘔吐, チアノーゼ, 流涎, 苦䦥等が主要症状とみられる.

6. 治療

胃洗浄, 諸種強心剂, 強肝解毒剂の投与, 輸液等 が行われ，対症的に鎮静，鎮座剂が用いられている. エンドリン服用後救助し得た例は少いが，救命例は 何れも早期に胃洗浄又は 䀦吐により薬剂の大部分 を体外泟除し得た例儿 限られるようである。そ の他人工呼吸, 酸素吸入 等が行われている.

\section{IV 潌括並びに考按}

動物実験倸よる毒性が 非常に強いに拘らず, ド リン剂中毒汇関する内外 の報告は非常飞少いが， 貨車で輸送中エンドリン が漏れ，次に同じ貨車で 運んだ小麦粉がエンドリ 
ンを吸収した為，その粉で造つたパンを食へ59人が 中毒症状を起した Davies12) 等の報告や，23才の男 子が $25.6 \mathrm{mg} / \mathrm{kg}$ アルドリンを服用し，速やか江胃 洗浄を行つたが中毒症状の発現を防ぐ事が出来ず， 20分以内に症摮が起きた Spiotta13) の報告があり， 又工業会社の従業員にみられた Nelson19) のデイル ドリン中毒例がある. Conley14) はマラリア、フィ ラリア対策としてのデイルドリン撒布者の慢性ディ ルドリン瞕業中毒の最初の調查報告をしており，同 時嫁庭で起つた 9 ケ月の幼女の急性中毒死亡例を 報告している. Patel26)等はボンベイでマラリア， フィラリア対策関係者のデイルドリン中毒を発表し， デイルトリンの慢性中毒にはアレルギー現象か関与 しているのではないかと云う仮説を発表した。 Hayes15はケニア，インドネシア等 5 ケ国にみられ た攏布者のテイルドリン中毒を報告し，皮闻污染の 握度が非常に重要であるととを強調している。一方 我か国では福原氏5) 等の自殺偟よるエンドリン中毒 2 死亡例の報告をみるのみである.

我が国でのドリン剂中毒の86\%は自殺によるもの でり，撒布中毒例は非常に少い，乙れは症状か柽 い為に赫告を行わない為かも知れず，又我か国では 撒布規模す小さく，撒布期間も短いので中毒が起り 傕いという点も存するであろう。ドリン剂は一般に 中枢神経の番状態を来大す神経毒であり，実質毒 であると云われているが Spiotta13) P E. Nelson19) 等の中毒例で蛋白尿や血尿を認めており，組織的 に肝, 罥の変性壊死が認められている.

Blazquez32）等は人のデイルドリン中毒を柽症， 中等症，重症に分古，埾症として頭湇，弱視，めま い, 軽い不䯣意運動, 発汗, 不眠, 悪蓦, 悪心, 全 身连和感をあげ，中等症では上記症状の他更に全筋 肉群の強い座攀が加わり，激しい例では瞬間的意諳 震失を伴う，重症ではてんかん様座慗が特徽的で意 識寝失を伴うが翼尿の失禁はなかつたと云つている。 Davies12）等の卸告はエンドリンの中，埾症中表

文

1) 山本 亮: 新㵨薬研究法, 1, 南山堂, 昭33.

2）池田良雄：䔉物致死显集 3 版，220，南山堂， 昭31.

3）福永一夫他 1 名：農薬化学, 日刊工業新間社, 昭35.
例であつて中枢神経不安を示し，意識啔失ててんか ん様氫整を示したものもあり，大部分は领用後 3 㭙 閒で発病し，恢復は速やかで痙攀を起した例も含め て大部分は翌日には全くよくなつたと感じたと述ぺ ている.

噇孔についてみると本統計では，散瞳を記载して いるものか17.7\%，維朣を記栈しているすのが9.7 \%あるが著者の動物実験の成綨では縮瞳を示すすの は全くみられなかつた。

服用量の少い 3ce 内服例及び $5 \mathrm{cc}$ 服用例何れむ 死亡しており略尔 $14.2 \mathrm{mg} / \mathrm{kg} \sim 19.5 \mathrm{mg} / \mathrm{kg}$ に当り， 人間に対する経口毒性も非常に強いあのと推定され 3.

\section{V 結 論}

1. 我が国でのドリン剂中毒は、アルドリン中毒 1例を除き，全例エンドリン中毒で，デイルドリン 中毒は報告されていない。

2. エンドリン中毒の86\%は自殺の目的による内 服死亡例であり，撒布中毒は非常に少い，

3. 季節の関係で住 5 月から11月に多く, 20 30 才に多い，男女別では女に稍々多い。

4. 服用量では $3 \mathrm{cc} の 1$ 例及び $5 \mathrm{cc} の 1$ 例 $10 \mathrm{cc}$ 服用の 2 例は何れあ死亡し，人に対する，エンドリ ンの経口青性も非常に強く, 略々 $14.2 \sim 48.8 \mathrm{mg} / \mathrm{kg}$ と推定される.

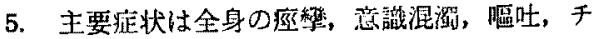
アノーゼ，流延，苦問等である。

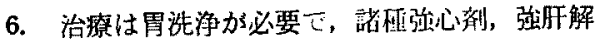

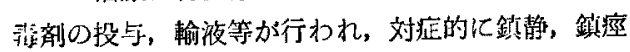
戋が用いられている。

擱筆するに当り御指導御校閲をいただいた恩師平

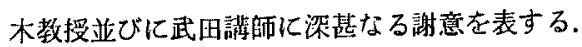

本稿の要旨は第17回日朴内科学会中团四国地方会 に於いて発表した。

献

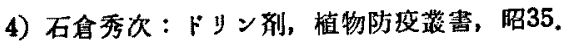

5）福原尚文他 4 名：農愁殺虫剂エンドリン中毒の 目䮖例，綜合臨床， $10: 847$, 昭 36 。

6）佐藤㐨太郎：DIELDRIN の慢性毒性，とくK

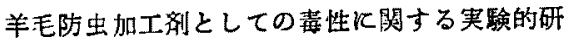


究, 座業医学, 4: 701 715, 昭37.

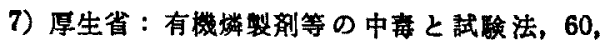
1660 .

8）厚生省：農薬の中毒と武験法，74，1961.

6）山崎料男他 1 名: コキプリのデイルドリン中毒 症状と神程機能, 防虫科学，23：47 54，1958,

10）森林太郎：諸種血液毒の家鬼未梢血液像並火兴 觯像化及す影震，日血会誌，14:192，昭26.

11）大野敏夫：骨醚細胞成分の血液像並飞造血脿器

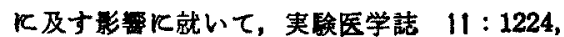
昭 2 .

12) Davies, G. M. et al.: Out break of food-poisoning from bread made of chemically contaminated flour. Brit. med. J. 2: 393, 1956.

13) Spiotta, E. J.: Aldrin Poisoning in man. A. M. A. Arch. industr. Hyg., $4: 560,1951$.

14) Conley, R. E.: Occupational Dieldrin poisoning. J. A. M. A., 172: 2077, 1960.

15) Hayes, W. J.: The toxicity of Dieldrin to man. Bull. World Health Organ., 20: 891, 1959.

16) Bunderen, J. et al.: Absurption and Toxicity of Dieldrin. (Proceedings of the Soriety for Experi. Biology and Med., 79: 236, 1952.

17) Fletcher, T. E. et al Exposure of Spray-Man to Dieldrin in Residual spraying, Bull. World Health Organ. 20: 15-25, 1959.

18) Hayes, W. J.: Dieldrin poisoning in man. Pub. Health Rep. 72: 1087-1091 (Dec.) 1957.

19) Nelson, E.: Aldrin poisoning. Rocky nountain M. J. $50: 483 \sim 486$. (June 1953).

20) Patel, T.B. et al: Dieldrin poisoning in man. Brit. Med. J. 1: 919 621. (April 19) 1958.

21) Princi, F. et al : A study of Workers Exposed to The Insecticides chlordan, Aldrin, Dieldrin. A. M. A. Arch. of Indust. Hyg. and Occup. Med. 3 : 64 72, 1951.

22) Treon J. E. et al: Toxicity of Certain chlorinated Hydrocarbon Insecticides for Laboratary
Animals, with Special Reference to Aldrin and Dieldrin. Agricultural and Food Chemiatry. 3: 402 408, 1955.

23) Klimmer, O. R.: Experimentelle Untersuchungen ther die Toxikologie insecticider chlorierter Kohlen wasser stoffe. Arch. exper. Path. u. Pharmakol. 227: 183 195, 1955.

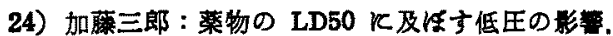
日本薬物学雑誌 36，(1942)，37，(1943).

25）黑田敦：BHC の病理作用闻関与る実験的研 究. 大阪医大誌, 13：115 151 (1952).

26）加納 清：BHC の毒性飞関与る研究. 日本䚘 生学誌, $8:(4.5,1954), 9:(1,1954)$.

27）沢田藤一郎： $\gamma$ BHC 中毒飞続発し筋萎綰性側 索硬化症様症状を呈した背賄炎と考へられる一 症例，日本医事新報，1723：44, 昭32.

28) Friberg, L. et al: Case of Panmyelophthisis after Exposure to Chlorophenothane and Benzene Hexachloride. Arch. Ind. Hyg. Oecup. Med. 8: 166 169, 1953.

29) Danopoulos, E. et al: Serious poisoning by Hexachlorocyclohe zane. Arch. Ind. Hyg. Occup. Med. 8: 582 587, 1953.

30) Smith, N. J.: Death Following Accidental Ingestion of DDT. J. Am. Med. Ass. 136: 469 471, 1948.

31) Treon, T. F.: Report of Kettering Lab. Univ. of Cincinnati, Dec. 1954 and Feb. 1955.

32) Blazquez, J. et al: New Cases of Chronic Occupational poisoning by Dieldrin. Bol. Ofic. San. Panam. 43: 121 129 (aug.) 1957. Cited in Arch. Indust. Heglth. 18: 337, 1958.

33）植松義則：有機橉剂中毒飞関する研究. 岡山医 学会誌, $71 ： 6099$, 昭34.

34) Hiraki, K. et al: The method of tissue culture (mainly of the bone-marrow) and a simple methode of Observing living tissure. Acts Med. Okayame 10: 99, 1956.

35) Borgmann, A.R. et al: Toxicological Studies of Dieldrin on small Laboratory Animals. Report of Kettering Lab. 1952. 


\title{
Studies on Drin Intoxication \\ III. Statistical Observations of Drin Intoxication
}

\author{
Yoshiharu Niiya
}

Department of Internal Medicine, Okayama University Medical School

(Director: Prof. Kiyoshi Hiraki)

1. Endrin was responsible for all the cases of drin intoxication reported in Japan except one attributed to aldrin.

No dieldrin intoxication has been reported.

2. Endrin was ingested with the suicidal purpose in $86 \%$ of the cases, intoxication due to its spray was rare.

3. Many of the accidents occurred betweeu the month of May and Novenber, and many of the victims were between the age of 20 and 30 .

More females were killed than males.

4. Oral intake of $3 c c$ or $5 c c$ of endrin was fatal in one case, respectively, and ingestion of its $10 \mathrm{cc}$ killed two persons.

In these cases the fatal doses were estimated at $14.2,19.5$ and $48.8 \mathrm{mg} / \mathrm{kg}$, respectively.

5. Cardinal symptoms included generalized seizure, loss of consciousness, romiting, cyanosis, salivation, and agony.

6. Treatment consists of gastrolavage injection of cardiotonics and liver-protecting agents, and infnsion.

Symptomatically sedatives and spasmolytics are also teneficial. 